\title{
A New Species of Catolesia (Asteraceae, Eupatorieae) from Bahia, Brazil
}

Author(s): Nádia Roque, Abel A. Conceição, and Harold Robinson

Source: Novon: A Journal for Botanical Nomenclature, 19(4):507-510. 2009.

Published By: Missouri Botanical Garden

DOI: http://dx.doi.org/10.3417/2008036

URL: http://www.bioone.org/doi/full/10.3417/2008036

BioOne (www.bioone.org) is a nonprofit, online aggregation of core research in the biological, ecological, and environmental sciences. BioOne provides a sustainable online platform for over 170 journals and books published by nonprofit societies, associations, museums, institutions, and presses.

Your use of this PDF, the BioOne Web site, and all posted and associated content indicates your acceptance of BioOne's Terms of Use, available at www.bioone.org/ page/terms_of_use.

Usage of BioOne content is strictly limited to personal, educational, and noncommercial use. Commercial inquiries or rights and permissions requests should be directed to the individual publisher as copyright holder. 


\title{
A New Species of Catolesia (Asteraceae, Eupatorieae) from Bahia, Brazil
}

\author{
Nádia Roque \\ Departamento de Botânica, Herbário ALCB, Universidade Federal da Bahia, Av. Ademar de \\ Barros, s/n, Ondina, 40171-970, Salvador, Bahia, Brazil. nroque@ufba.br
}

Abel A. Conceição

Departamento de Ciências Biológicas, Herbário HUEFS, Universidade Estadual de Feira de Santana, Km 03, BR 116, 44031-460, Feira de Santana, Bahia, Brazil

\section{Harold Robinson}

U.S. National Herbarium, National Museum of Natural History, Smithsonian Institution, MRC 166, Washington, D.C. 20013-7012, U.S.A.

Abstract. Catolesia D. J. N. Hind is an endemic, previously monotypic genus (Asteraceae, Eupatorieae) from the campos rupestres of Bahia, Brazil. A second species for the genus, C. huperzioides Roque, H. Robinson \& A. A. Conceição, is recognized and described here. It is distinguished from C. mentiens D. J. N. Hind principally by the well-organized terminal synflorescence composed of (7)8 to 12 capitula, of which one is central and larger, its shorter leaves (4-5 mm vs. 7-19 mm in C. mentiens), its white corolla (vs. pink), and the pappus (a brief crown to $0.1 \mathrm{~mm}$ vs. mostly absent). Catolesia huperzioides is known only from the municipality of Mucugê and is probably endemic to the Chapada Diamantina Region of Bahia, Brazil.

Key words: Brazil, Catolesia, Compositae, Gyptidinae, IUCN Red List.

Catolesia D. J. N. Hind was recently described (Hind, 2000b) as a monotypic genus for the tribe Eupatorieae (Asteraceae) based on the taxon $C$. mentiens D. J. N. Hind. The genus exhibited obvious affinities with the subtribe Gyptidinae, especially in its spirally inserted leaves, the biseriate and not imbricate involucre, the paleaceous receptacle, the narrowly funnelform corolla tubes, and the eppapose cypsela with more or less procurrent upper margins to the carpopodium (Hind, 2000b).

The subtribe Gyptidinae of the tribe Eupatorieae is distributed mostly in eastern South America, with its greatest taxonomic diversity in the campos rupestres of Brazil. Of the 29 genera and ca. 135 species in the subtribe, 13 genera are exclusively Brazilian and nine are restricted to the state of Bahia (Hind \& Robinson, 2007).

The taxonomy of the Gyptidinae has recently been discussed by Hind (1999, 2000a, b; Hind \& Robinson,
2007), and three informal groups were recognized within the subtribe. Catolesia falls clearly into Hind's second group with "many-flowered capitula, densely spirally inserted leaves and many with variously defective pappus setae" (2000b: 944). According to Hind, Catolesia and Agrianthus Martius ex DC. are the only genera in the subtribe that possess paleaceous receptacles. However, Agrianthus differs by its pubescent stems, scale-like leaves that are densely prominently veined and without any hint of succulence, (2)3- to 5-seriate phyllaries, clavate style branches, and setiform pappus.

The new taxon is described and illustrated and ecological information is provided. The data presented here are based on literature revisions and an analysis of Catolesia collections and types available at ALCB, HUEFS, and US. Morphological studies using an Olympus SZH10 stereomicroscope (Olympus, Tokyo, Japan) were carried out on dried material.

Catolesia huperzioides Roque, H. Robinson \& A. A. Conceição, sp. nov. TYPE: Brazil. Bahia: Mpio. Mucugê, Chapada Diamantina, Serra do Esbarrancado, $12^{\circ} 43^{\prime} \mathrm{S}, 41^{\circ} 30^{\prime} \mathrm{W}, 5$ Sep. 2006, $A$. $A$. Conceição \& P. D. Carvalho 1804 (holotype, HUEFS). Figures 1, 2.

Haec species a Catolesia mentiente D. J. N. Hind synflorescentia terminali ex capitulis aggregatis sessililibus biformibus constante, foliis brevioribus ( $4-5 \mathrm{~mm}$ longis), corollis albis et pappo breviter coroniformi ca. $0.1 \mathrm{~mm}$ longo semper praesente distincta.

Candelabriform shrub $0.6-0.9 \mathrm{~m}$; stems $0.4-1 \mathrm{~cm}$ diam., glabrous, branched from base, 6 to 8 branches pseudowhorled beneath old synflorescences, densely leafy in upper half, leaf blades lost on older stem but sheaths persistent. Leaves densely spiraled, imbri- 


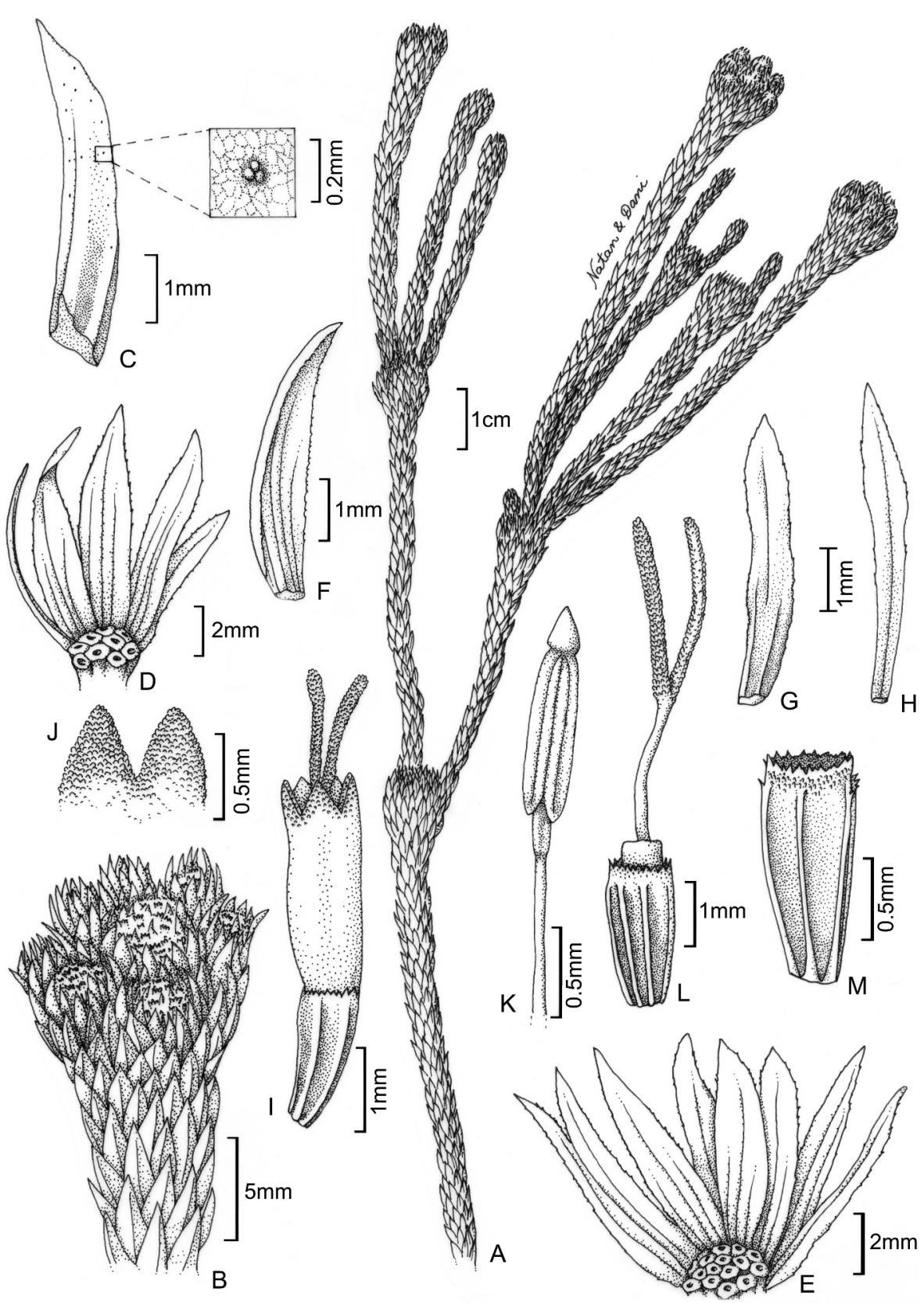

Figure 1. Catolesia huperzioides Roque, H. Robinson \& A. A. Conceição. - A. Fertile habit. —B. Synflorescence on the apex of the branch showing eight capitula, with the central one significantly larger. —C. Detail for the lanceolate, somewhat succulent leaf with a cluster of three glandular dots shown at right. —D. Receptacle and involucre of a peripheral capitulum. -E. Receptacle and involucre of the central capitulum. - F. Outer phyllary. — G. Inner phyllary. —H. Palea. - I. Floret. -J. Papillose apices of two corolla lobes. - K. Stamen, showing appendage and collar. —L. Floret dissected to show the nectary surrounding the stylar base. - M. Cypsela with a short dentate to laciniate coroniform pappus. Drawn from the holotype A. A. Conceição \& P. D. Carvalho 1804 (HUEFS).

cate, sessile, simple, concolorous, lanceolate, slightly succulent in appearance, blades $4-5 \times 0.7-0.9 \mathrm{~mm}$, adaxially glabrous and pitted with 1 or an assemblage of glandular dots, abaxially glabrous, midrib carinate in both sides, blade margins in distal half undulate, apices acute, pungent and incurved. Synflorescences terminal, corymbose, more than 200 in a single plant, each $0.5-1 \mathrm{~cm}, 1-1.5 \mathrm{~cm}$ diam., hemispheric, sur- 

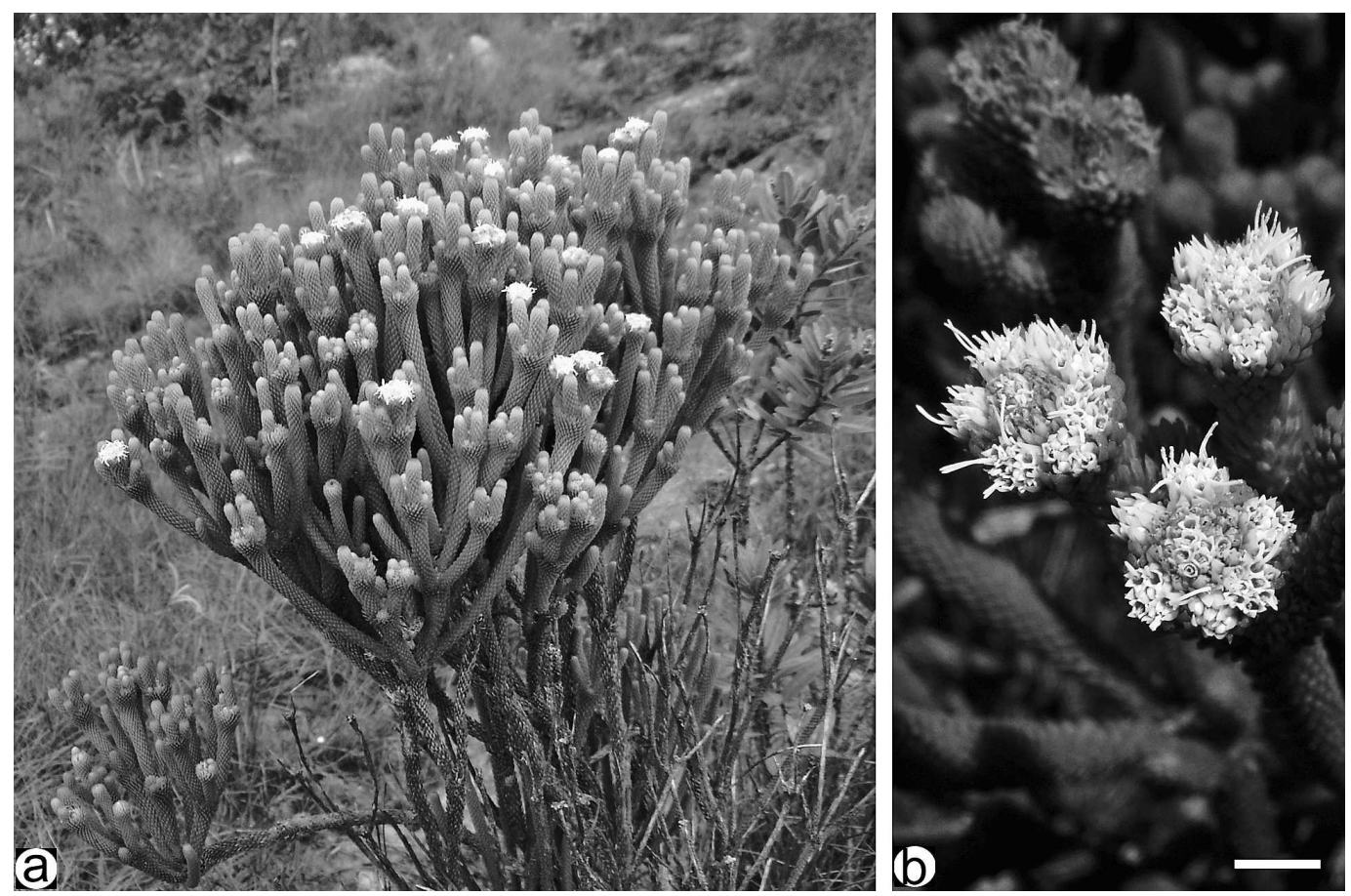

Figure 2. Catolesia huperzioides Roque, H. Robinson \& A. A. Conceição. - A. Photo showing candelabriform habit and the strongly imbricate leaves. - B. Detail for three anthesal synflorescences revealing one larger central capitulum surrounded by ca. seven peripheral capitula. Photos by Abel A. Conceição taken at Mucugê, Bahia. Scale bar $=0.5 \mathrm{~cm}$.

rounded by leaves subequal to the capitula; each synflorescence with (7)8 to 12 capitula, with 1 capitulum central and larger by its width and additional florets. Capitula homogamous, discoid, cylindric, sessile, the peripheral capitula $6-7 \mathrm{~mm}$, 2-3 mm diam., the central capitulum 6-7 mm, ca. $5 \mathrm{~mm}$ diam.; bracteoles 3 to 5 per capitulum, leaflike, thick, linear, $4-5 \times$ ca. $0.5 \mathrm{~mm}$, outer surface and margins glandular-punctate in the epidermal pits, margins entire, ciliate, apices acute, mucronate. Involucre campanulate, phyllaries biseriate, cream, 17 to 20 , distant, subequal, outer phyllaries 8 to 10 , persistent, slightly keeled, with base inflated, lanceolate, $4-4.5 \times$ ca. $0.5 \mathrm{~mm}$, glabrous, margins slightly sinuate with stipitate-glandular cilia, apices acute, inner phyllaries 9 to 10 , easily falling, slightly keeled, with base inflated, lanceolate, ca. $5 \times 0.8-1.2 \mathrm{~mm}$, margins with stipitate-glandular cilia, apices acute; receptacle convex, alveolate, glabrous, paleaceous, paleae 4 to 6 , scattered among flowers, deciduous, slightly keeled, with base inflated, linear to spatulate, 4-5 $\times 0.5-0.7 \mathrm{~mm}$, glabrous, margins with stipitateglandular cilia, apices acute. Flowers bisexual, ca. 10 in peripheral capitula and 26 to 30 in central capitulum, 4.5-5.5 mm, corolla white, actinomorphic, 2.5-3 $\times$ ca. $1 \mathrm{~mm}$, glabrous, corolla lobes 5 , narrowly triangular, ca. $0.5 \mathrm{~mm}$, papillose outside, margins involute; anther cylinder included within corolla

Table 1. Morphological differences between Catolesia huperzioides Roque, H. Robinson \& A. A. Conceição and C. mentiens.

\begin{tabular}{|c|c|c|}
\hline Characters & C. mentiens & C. huperzioides \\
\hline Leaf shape & narrowly oblanceolate & lanceolate \\
\hline Leaf size (mm) & $7-19 \times 1.1-2.1$ & $4-5 \times 0.7-0.9$ \\
\hline Capitula & $\begin{array}{l}\text { in loose groups at branch apices, capitula } \\
\text { similarly sized, pedunculate }\end{array}$ & $\begin{array}{l}\text { a synflorescence with }(7) 8 \text { to } 12 \text { congested at branch } \\
\text { apices, the central capitulum notably larger, all } \\
\text { capitula sessile }\end{array}$ \\
\hline Florets & ca. 20 , corolla pink & $\begin{array}{l}\text { ca. } 10 \text { in peripheral capitula and } 26 \text { to } 30 \text { in central } \\
\text { capitulum, corolla white }\end{array}$ \\
\hline Pappus & $\begin{array}{l}\text { absent or very rarely with minute abortive } \\
\text { setae on apical callus }\end{array}$ & short dentate to laciniate crown ca. $0.1 \mathrm{~mm}$ long \\
\hline
\end{tabular}


throat, oblong, ca. $1 \mathrm{~mm}$, apical anther appendages triangular, ca. $0.2 \mathrm{~mm}$, as long as wide, apices rounded, anther collar prominent and distinctly wider than filament; style ca. $3 \mathrm{~mm}$, style branches linear to filiform, ca. $1.5 \mathrm{~mm}$, papillose, nectary present. Cypsela 1.5-2 mm, 5-ribbed, glabrous; carpopodium inconspicuous; pappus a short dentate to laciniate crown ca. $0.1 \mathrm{~mm}$.

Habitat and distribution. Catolesia huperzioides was collected from campos rupestres, at the summit and slopes of the Serra do Esbarrancado from 1450$1700 \mathrm{~m}$, where there is frequent mist in the morning. The plants are found growing in sandy soil between rocks among herbs and shrubs. The new species is known only from the municipality of Mucugê and is probably endemic to the Chapada Diamantina Region of Bahia, Brazil.

IUCN Red List category. According to the available information about this species, it can be considered Critically Endangered (CR B1ab; B2ab) according to IUCN Red List criteria (IUCN, 2001) because of its restricted distribution (only one locality).

Etymology. The specific epithet alludes to the vegetative similarity of the new species to Huperzia mooreana (Baker) Holub (Lycophyta, Lycopodiaceae), a very common species in the Serra do Sincora that is also found in the Chapada Diamantina Region.

Discussion. Catolesia huperzioides has all of the characteristics that distinguish the genus. The plant is a candelabriform shrub, poorly branched at the base, moderately branched in the upper half, and pseudowhorled beneath old inflorescences; the leaves are slightly succulent and lack any nonglandular trichomes; the inflorescences are terminal and corymbose; and the receptacle is paleaceous. However, $C$. huperzioides has several interesting characters that distinguish the species. The principal differences include the leaves that are lanceolate with pungent and incurved tips (vs. narrowly oblanceolate, rather blunt, and not incurved at all in C. mentiens); smaller leaf blades (4-5 $\mathrm{mm}$ vs. $7-19 \mathrm{~mm}$ in C. mentiens); the capitula that form a highly congested terminal synflorescence composed of (7)8 to 12 capitula, sessile, congested, with the central capitulum markedly larger with twice as many florets (vs. the synflorescence in $C$. mentiens that is also composed of several capitula [10(to 12), rarely few (4)] but these more diffuse, similarly sized, and conspicuously pedunculate); and the cypsela with a short, coroniform pappus (vs. seta absent or abortive) (Table 1).

Catolesia huperzioides was collected in the same type of habitat as C. mentiens, in the campos rupestres of the Chapada Diamantina Region. Given the taxonomic diversity of the Gyptidinae in the campos rupestres, the discovery of the new species further supports the habitat as a major center of diversity for the subtribe within the state.

Paratypes. Brazil. Bahia: Mucugê, Chapada Diamantina, Serra do Esbarrancado, $12^{\circ} 44^{\prime} \mathrm{S}, 41^{\circ} 30^{\prime} \mathrm{W}, 24$ Feb. 2005, A. A. Conceição 1179 (HUEFS); Mucugê, Parque Nac. Chapada Diamantina, $12^{\circ} 42^{\prime} \mathrm{S}, 41^{\circ} 31^{\prime} \mathrm{W}, 4$ Mar. 2006, A. A. Conceição 1741 (HUEFS).

Acknowledgments. Special thanks to Natanael Nascimento and Daniela Guimarães for the line drawing in Figure 1; to the curators of ALCB, HUEFS, and US for making specimens available; and to the manuscript reviewers for their useful comments.

\section{Literature Cited}

Hind, D. J. N. 1999. A new genus, Semiria (Compositae: Eupatorieae: Gyptidinae), and a discussion of its affinities within the Gyptidinae of Bahia, Brazil. Kew Bull. 54: $425-432$.

-2000a. A new species of Lasiolaena (Compositae: Eupatorieae: Gyptidinae), and a synopsis of the genus. Kew Bull. 54: 915-925.

2000b. A new genus, Catolesia (Compositae: Eupatorieae), and a discussion of its affinities within the subtribe Gyptidinae of Bahia, Brazil. Kew Bull. 55: 941-948.

\& H. Robinson. 2007. Eupatorieae. Pp. 510-574 in J. W. Kadeiret \& C. Jeffrey (editors), The Families and Genera of Vascular Plants, Vol. 8: Flowering Plants, Eudicots, Asterales. Springer-Verlag, Berlin.

IUCN. 2001. IUCN Red List Categories and Criteria, Version 3.1. Prepared by the IUCN Species Survival Commission. IUCN, Gland, Switzerland, and Cambridge, United Kingdom. 